\title{
Synergistic Effects of Food Colors on the Toxicity of 3-Amino-1,4-dimethyl- 5H-pyrido[4,3-b]indole (Trp-P-1) in Primary Cultured Rat Hepatocytes
}

\author{
Hitoshi Ashida, ${ }^{1,2}$ Takashi Hashimoto, ${ }^{2}$ Shinji TsujI, ${ }^{1}$ Kazuki Kanazawa, $^{2}$ and Gen-ichi Danno ${ }^{1,2, *}$ \\ ${ }^{1}$ Department of Biofunctional Chemistry, Faculty of Agriculture, ${ }^{2}$ Division of Life Science, \\ Graduate School of Science and Technology, Kobe University, Nada-ku, Kobe 657-8501, Japan
}

(Received January 21, 2000)

\begin{abstract}
Summary The synergistic effect of food additives or food colors on the toxicity of 3amino-1,4-dimethyl-5H-pyrido[4,3-b]indole (Trp-P-1) was investigated using primary cultured rat hepatocytes. When hepatocytes from rats fed a standard diet were treated with a mixture of four major food additives (sorbitol, sodium L $(+)$-glutamate, benzoic acid, and propylene glycol) or a mixture of six typical artificial food colors (erythrosine, allura red, new coccine, brilliant blue, tertrazine, and fast green), the in vitro treated food-color mixture itself showed cytotoxicity: the reduction of cell viability and decreases in the activities of gluconeogenesis and ureogenesis. The food-color mixture enhanced cytotoxicity of Trp-P-1 obviously. We then investigated the effects of in vivo-dosed food additives or food colors on Trp-P-1-caused toxicity. Hepatocytes were isolated and cultured from rats fed a diet containing a mixture of food additives or a mixture of food colors with half the amount of their respective acceptable daily intake for $4 \mathrm{wk}$. Trp-P-1 was administered to the hepatocytes at various concentrations for $12 \mathrm{~h}$. Synergistic effects of in vivo-dosed food additives and food colors were not observed on Trp-P-1-caused cytotoxicity as estimated by a loss of cell viability and the reductions of DNA and protein syntheses. On the contrary, we have observed that in vivo administered food colors synergistically facilitated to reduce the activities of gluconeogenesis and ureogenesis in Trp-P-1-treated hepatocytes. These results suggest that the daily intake of artificial food colors may impair hepatic functions such as gluconeogenesis and ureogenesis, when dietary carcinogens are exposed to the liver cells.
\end{abstract}

Key Words food additives, food colors, Trp-P-1, primary cultured hepatocytes, rat

Our diet closely associates with cancer formation (1) because it should contaminate as low concentrations of environmental xenobiotics as possible and naturally occurring carcinogens: pyrolysates, mycotoxins, plant alkaloids, nitrites and nitrosamines (2-4). In addition, processed food usually contains artificial food additives and colors, which may act as xenobiotics in the human body (5-7). Food additives and colors are normally subjected to toxicity tests using animals before usage, and an acceptable daily intake (ADI) is determined according to the data obtained. However, toxicity tests are usually done by the administration of one food additive alone. To evaluate the risk that may occur by ingesting various chemicals at the same time, it would be important to study whether co-administration of food additives, naturally occurring food components and food contaminants would produce synergistic, additive, or antagonistic effects on the toxicity of chemicals.

It is difficult to obtain experimental evidence for the synergistic effect because the combinations of various chemicals are limitless and a number of animals are required to conduct experiments of this kind. Many cell lines are used for the screening of potential toxicity instead of experimental animals, but these cells often lack

* To whom correspondence should be addressed.

E-mail: danno@kobe-u.ac.jp certain functions of actual tissues or organs. Therefore, the data obtained from the experiments using cell lines are difficult to apply to living animals. On the other hand, primary cultured cells from tissues or organs usually maintain their original functions and the past nutritional status of animals (8-10). Especially, primary cultured hepatocytes are suitable models for the assessment of the toxicity of xenobiotics in different nutritional status, since the liver is the most dominant tissue for detoxification of xenobiotics via the cytochrome P450 system. Previously, we reported the cytotoxicy of various xenobiotics using primary cultured hepatocytes in rats fed different diets, and found that Trp-P-1, one of the dietary carcinogens, caused strong cytotoxicity to hepatocytes, and tolerance to Trp-P-1 was lowered in the hepatocytes from rats fed a high-protein diet $(10)$. Thus, Trp-P-1 is a good chemical for the evaluation of cytotoxicity to hepatocytes under co-treatment with other food-derived chemicals, although it is still unknown whether the cytotoxity is related to carcinogenicity.

In this study, we investigated whether food additives or colors show synergistic effects on the toxicity of TrpP-1. We measured the Trp-P-1-caused cytotoxicity and dysfunction in hepatocytes after in vitro pretreatment with a mixture of four food additives or a mixture of six food colors. Then, we studied the effects of in vivo- 
treated food additives or colors on Trp-P-1-caused alterations in hepatocytes. As a result, gluconeogenesis and ureogenesis were synergistically reduced in the cells from rats fed the mixture of food colors co-existing with Trp-P-1.

\section{MATERIALS AND METHODS}

Materials. As food additives, sodium $\mathrm{L}(+)$-glutamate, benzoic acid, and propylene glycol were purchased from Wako Pure Chemical Industries, Ltd. (Osaka, Japan). Sorbitol, new coccine (red 102), brilliant blue (blue 1), tartrazine (yellow 4), and fast green (green 3) were obtained from Tokyo Chemical Industry Co. (Tokyo, Japan). Erythrosine (red 3) and allura red (red 40) were products of Daiwa Chemical Industry Co. (Saitama, Japan). For the culture of hepatocytes, fetal bovine serum (FBS) and William's medium E were purchased from Life Technologies, Inc. (Tokyo, Japan). Tryptophan pyrolysis product, Trp-P-1, and supplements for the medium were obtained from Wako Pure Chemical Industries. Other chemicals were of the highest purity grade available.

Animals and diets. Male Wistar rats (ST, SPF: Japan SLC, Inc. Shizuoka, Japan), 3-wk-old and each weighing about $50 \mathrm{~g}$, were housed in stainless-steel cages in a temperature-controlled $\left(24 \pm 1^{\circ} \mathrm{C}\right)$ room with $60 \pm 5 \%$ humidity and a 12-h light-dark cycle. Rats were divided into three groups at random and received water and the following diets ad libitum for $4 \mathrm{wk}$. The standard diet was prepared according to the American Institute of Nutrition AIN-76 semipurified diet $(11,12)$, which consisted of $20 \%$ (w/w) milk casein, $50 \%$ sucrose, $15 \%$ corn starch, 5\% corn oil, 5\% cellulose powder, $3.5 \%$ AIN mineral mixture, $0.3 \%$ DL-methionine, $0.2 \%$ choline bitartrate and 1\% AIN vitamin mixture. The food additives-containing-diet was prepared by adding $12.5 \mathrm{mg}$ sorbitol, $12.5 \mathrm{mg}$ sodium $\mathrm{L}(+)$-glutamate, $2.5 \mathrm{mg}$ benzoic acid and $12.5 \mathrm{mg}$ propylene glycol to $100 \mathrm{~g}$ of the standard diet. The food colors-containingdiet was also prepared by adding $1.25 \mathrm{mg}$ erythrosine $\mathrm{B}, 3.5 \mathrm{mg}$ allura red AC, $0.063 \mathrm{mg}$ new coccine, $6.25 \mathrm{mg}$ brilliant blue, $3.75 \mathrm{mg}$ tartrazine and $6.25 \mathrm{mg}$ fast green. The amounts of these chemicals were decided by using half of their ADI values, except sorbitol and sodium $\mathrm{L}(+)$-glutamate: these two chemicals were added following the half ADI value of propylene glycol because their ADI values are not defined in Japan. These food additives and colors are commonly produced and consumed in Japan. Although respective combinations do not apply in practical use for one food, we have various kinds of food containing some or all of these food additives and colors. The body-weight gain of rats fed food additives or food colors was identical to that of rats fed the standard diet alone.

The content of cytochrome P450 and the activities of the drug metabolizing enzymes in a microsomal fraction of the rat liver. After $4 \mathrm{wk}$ feeding of each diet, the rats were killed and their livers subjected to preparation of a microsomal fraction. After perfusion with ice-cold 1.15\% $(\mathrm{w} / \mathrm{v}) \mathrm{KCl}$, the liver was homogenized with 3 volumes of
$\mathrm{KCl}$. The homogenate was centrifuged at $9,000 \times g$ for $20 \mathrm{~min}$, and the supernatant was further centrifuged at $105,000 \times g$ for $60 \mathrm{~min}$. The precipitate was suspended in distilled water with a Potter homogenizer, and the suspension obtained was used in the following experiments as the microsomal fraction. The contents of cytochrome $\mathrm{P} 450$ and cytochrome $\mathrm{b}_{5}$ were determined by the method of Omura and Sato (13). The activities of NADPH- cytochrome c reductase (14), cytochrome $b_{5}$ reductase (15), aniline hydroxylase (16), and aminopyrine $N$-demethylase $(17,18)$ were also measured.

Primary culture of hepatocytes. Another group of rats was subjected to the isolation of hepatocytes by in situ perfusion of collagenase according to the method of Tanaka et al. (19). Isolated hepatocytes were suspended at the concentration of $5 \times 10^{5}$ cells $/ \mathrm{mL}$ into William's medium E containing 5\% (v/v) FBS, kanamycin $(60 \mathrm{mg} / \mathrm{L})$, aprotinin $(5 \mathrm{kIU} / \mathrm{L}), 1 \mathrm{~nm}$ insulin and $1 \mathrm{~nm}$ dexamethasone. The cells were seeded onto plastic dishes (Sumitomo Bakelite Ltd., Japan) precoated with collagen type I and cultured under 95\% air-5\% $\mathrm{CO}_{2}$ at $37^{\circ} \mathrm{C}$ for $6 \mathrm{~h}$. After the medium was removed, the cells were washed twice with phosphate-buffered saline (PBS) and used as the zero-time cells. The zero-time cells were treated with various concentrations of Trp-P1. Trp-P-1 was dissolved in dimethyl sulfoxide (DMSO) and pre-mixed in serum-free medium $(1: 1,000, \mathrm{v} / \mathrm{v})$. Control cells were given DMSO as a vehicle. After treatment for $12 \mathrm{~h}$, hepatocytes were washed twice with icecold PBS and subjected to the following experiments.

Measurement of cytotoxicity. The cytotoxicity of Trp-P-1 to hepatocytes was judged by measuring the cell viability and membrane damage. The cell viability was estimated by using 3-(4,5-dimethyl-2-thiazolyl)2,5-diphenyl-2H-tetrazorium-bromide (MTT) assay $(20,21)$ with a slight modification as described previously (10); 96-well plates with hepatocytes in $0.1 \mathrm{~mL}$ medium. For the assessment of membrane damage, lactate dehydrogenase (LDH) activities in both the medium and cell homogenate were measured; 12-well plates with hepatocytes in $0.7 \mathrm{~mL}$ medium $(10,22)$. The $\mathrm{LDH}$ leakage into the medium was expressed as a percent of the sum of activity in medium and cell homogenate.

Measurement of DNA and protein syntheses. Hepatocytes on 24-well plates with $0.35 \mathrm{~mL}$ medium were labelled with $0.5 \mu \mathrm{Ci} / \mathrm{mL}$ [methyl- $\left.{ }^{3} \mathrm{H}\right]$-thymidine (20 Ci/mmol; NEM-Dupont, MA) for DNA synthesis or $0.5 \mu \mathrm{Ci} / \mathrm{mL} \quad \mathrm{L}-\left[4,5-{ }^{3} \mathrm{H}(\mathrm{N})\right]$-leucine $\quad(40-60 \mathrm{Ci} / \mathrm{mmol}$; NEM-Dupont) for protein synthesis for $4 \mathrm{~h}$. After the medium was removed, the cells were washed with icecold PBS twice and dissolved in $1 \mathrm{~N} \mathrm{NaOH}$ solution containing $1 \mathrm{~mm}$ thymidine, $0.1 \%(\mathrm{v} / \mathrm{v})$ Triton $\mathrm{X}-100$ and $0.1 \%(\mathrm{w} / \mathrm{v})$ sodium lauryl sulfate for DNA synthesis, or $10 \mathrm{~mm}$ Tris-HCl buffer ( $\mathrm{pH} 7.4$ ) containing 2 mm EDTA, $1 \mathrm{mg} / \mathrm{mL}$ leucine, $0.1 \%$ Triton $\mathrm{X}-100$ and $0.1 \%$ sodium lauryl sulfate for protein synthesis. An aliquot volume of each cell lysate was spotted onto a glass filter, and the filter was washed with ice cold $5 \%(\mathrm{w} / \mathrm{v})$ trichroloacetic acid five times, with ethanol, and with acetone. The radioactivity fixed onto the filter was measured by a liquid 
scintillation counter.

Measurement of ureogenesis and gluconeogenesis. The activities of ureogenesis and gluconeogenesis were measured in Trp-P-1-treated hepatocytes on 24-well plates with $0.35 \mathrm{~mL}$ medium as follows. For the measurement of ureogenesis, the cells were washed with Earle's buffer twice and incubated with the same buffer solution containing $5 \mathrm{~mm}$ ammonium chloride as a substrate for $2 \mathrm{~h}$. Urea concentration in the cell-free buffer was determined by the method of Marsh et al. (23). For the measurement of gluconeogenesis, the cells were washed with glucose-free Earle's buffer twice and incubated with the same buffer containing $5 \mathrm{~mm}$ fructose or $5 \mathrm{~mm}$ pyruvate as the substrate for $30 \mathrm{~min}$. The amount of released glucose was quantified with a glucose assay kit (Wako Pure Chemical Ind.).

Measurement of protein content. Protein content in the homogenate and the subcellular fractions were measured by the method of Lowry et al. (24), with bovine serum albumin as the standard.

In vitro pretreatment with food additives or food colors to hepatocytes. For in vitro experiments, food additives or colors were pretreated with hepatocytes from the standard diet-fed rats for $12 \mathrm{~h}$, and various concentrations of Trp-P-1 were added to the cells and cultured for another $12 \mathrm{~h}$. The concentration of food additives or colors in the culture medium was $1 / 5,000$ of that in the diet used in vivo experiments: the food additives mixture consisted of $25 \mu \mathrm{g}$ sorbitol, $25 \mu \mathrm{g}$ sodium $\mathrm{L}(+)$-glutamate, $5 \mu \mathrm{g}$ benzoic acid, and $25 \mu \mathrm{g}$ propylene glycol in one liter of medium, and the food colors mixture consisted of $2.5 \mu \mathrm{g}$ erythrosine, $7.0 \mu \mathrm{g}$ allura red, $0.126 \mu \mathrm{g}$ new coccine, $12.5 \mu \mathrm{g}$ brilliant blue, $7.5 \mu \mathrm{g}$ tartrazine, and $12.5 \mu \mathrm{g}$ fast green per liter. After the treatment with Trp-P-1, hepatocytes were subjected to MTT assay, LDH-leakage test, and measurements of the activities of gluconeogenesis and ureogenesis.

Statistical analysis. Data were expressed as mean \pm SE. Statistical analysis was performed by a computer using Stat View (ver. 4.0). Data for the effects of food additives or colors were analyzed by two-way fractional ANOVA, and a separate analysis was carried out to determine the significance of Trp-P-1 in each diet group by one-way fractional ANOVA with multiple comparison tests using Scheffe's method as a post-hoc test. The 0.05 level of probability was used as the criterion for significance.

\section{RESULTS}

In vitro pretreatment with food additives or colors to hepatocytes

The direct actions of food additives and colors to hepatocytes were examined. The cells were pretreated with the mixture of food additives and colors for $12 \mathrm{~h}$ before adding the various concentrations of Trp-P-1. A mixture of food colors by itself decreased the cell viability (Fig. 1A) without membrane damage (Fig. 1B). In addition, food colors synergistically facilitated Trp-P-1induced cell death: the significant effects of food colors were observed against the untreated cells in the reduc-
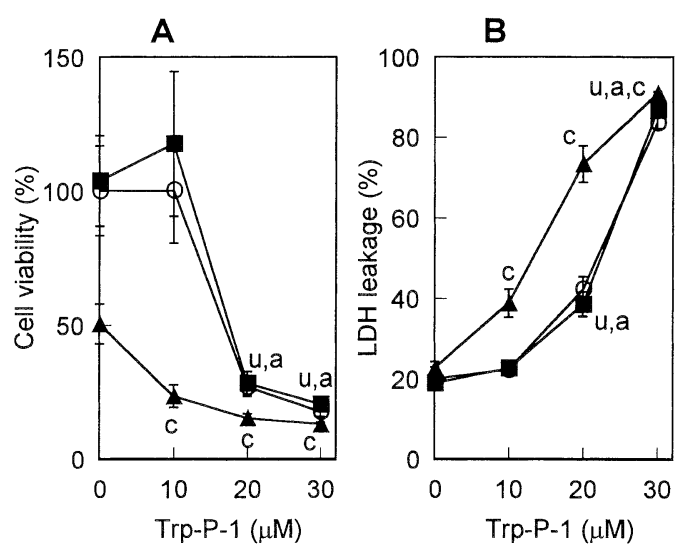

Fig. 1. In vitro effects of food additives and colors on cell viability and lactate dehydrogenase $(\mathrm{LDH})$-leakage in Trp-P-1-treated hepatocytes. Hepatocytes were isolated and cultured from standard diet-fed rats. After a 6-h-culture, hepatocytes were pretreated with a mixture of food additives $(\boldsymbol{\square})$ or colors $(\boldsymbol{\Delta})$ for $12 \mathrm{~h}$, and then various concentrations of Trp-P-1 were added for another $12 \mathrm{~h}$. Control cells $(\bigcirc)$ were treated with $0.1 \%$ dimethyl sulfoxide (DMSO) as a vehicle. The cell viability was measured in hepatocytes by MTT-assay (panel A) and LDH-leakage test (panel B) as described in Materials and Methods. Data are mean \pm SE from four independent experiments. Significant effects of food colors were observed against untreated hepatocytes for both cell viability and LDH-leakage $(p<0.05)$ by twoway fractional ANOVA. $\mathrm{u}$, a, and $\mathrm{c}$ designate significant differences between treatment with Trp-P-1 and DMSO in untreated, food additives- and food colorspretreated cells, respectively $(p<0.05)$, by one-way fractional ANOVA and multiple comparison tests using Scheffe's method as a post-hoc test.

tion of cell viability (Fig. 1A) and the induction of membrane damage (Fig. 1B) in the presence of Trp-P-1. On the other hand, the mixture of food additives did not show any synergistic effect.

Pretreatment with food colors by themselves also decreased the activities of gluconeogenesis (Fig. 2A and B) and ureogenesis (Fig. 2C). Significant effects of food colors were detected after treatment with Trp-P-1 for both gluconeogenesis and ureogenesis. These results indicate that in vitro-treated food colors have synergistic effects on Trp-P-1-induced cytotoxicity and the reduction of gluconeogenesis and ureogenesis.

Effect of food additives or colors on the activities of drug-metabolizing enzymes in a microsomal fraction of rat

The effects of food additives and colors on Trp-P-1caused toxicity were investigated. To begin with, we measured the contents and activities of drug-metabolizing enzymes in rat liver after 4-wk feeding of each diet. As shown in Table 1, both food additives and colors did not affect the contents of cytochrome P450 and $b_{5}$ or the activities of the drug-metabolizing enzymes tested here. These results indicate that rats did not recognize food additives and colors as xenobiotics at the dosage used in this study. 
Table 1. Effect of the diet on the content of cytochrome P450 and the activities of drug-metabolizing enzymes in the liver of rats fed food additives or colors.

\begin{tabular}{|c|c|c|c|c|c|c|}
\hline \multirow{2}{*}{ Diet } & Cytochrome P450 & Cytochrome $b_{5}$ & $\begin{array}{c}\text { NADH-cytochrome } \\
\text { c reductase }\end{array}$ & $\begin{array}{l}\text { Cytochrome } b_{5} \\
\text { reductase }\end{array}$ & $\begin{array}{c}\text { Aniline } \\
\text { hydroxyrase }\end{array}$ & $\begin{array}{l}\text { Aminopyrine } \\
N \text {-demethyrase }\end{array}$ \\
\hline & \multicolumn{2}{|c|}{ Content (nmol/mg protein) } & \multicolumn{2}{|c|}{ Activity ( $\mu \mathrm{mol} / \mathrm{min} / \mathrm{mg}$ protein) } & \multicolumn{2}{|c|}{ Activity (nmol/min/mg protein) } \\
\hline Standard & $0.843 \pm 0.114$ & $0.277 \pm 0.026$ & $0.121 \pm 0.014$ & $6.16 \pm 0.48$ & $0.509 \pm 0.059$ & $5.93 \pm 0.87$ \\
\hline Food additives & $0.696 \pm 0.095$ & $0.261 \pm 0.012$ & $0.137 \pm 0.021$ & $5.80 \pm 0.65$ & $0.536 \pm 0.068$ & $5.45 \pm 1.08$ \\
\hline Food colours & $0.828 \pm 0.076$ & $0.286 \pm 0.017$ & $0.133 \pm 0.020$ & $6.80 \pm 0.85$ & $0.664 \pm 0.060$ & $5.99 \pm 0.79$ \\
\hline
\end{tabular}

Hepatic microsomal fraction was prepared from standard diet-, food additives- or food colors-fed rats separately. The contents of cytochrome $\mathrm{P} 450$ and $\mathrm{b}_{5}$, and the activities of $\mathrm{NADH}$-cytochrome $\mathrm{c}$ reductase, cytochrome $\mathrm{b}_{5}$ reductase, aniline hydroxyrase and aminopyrine $\mathrm{N}$-demethyrase were measured in the microsomal fraction as described in Material and Methods. Results are mean \pm SE from six rats.

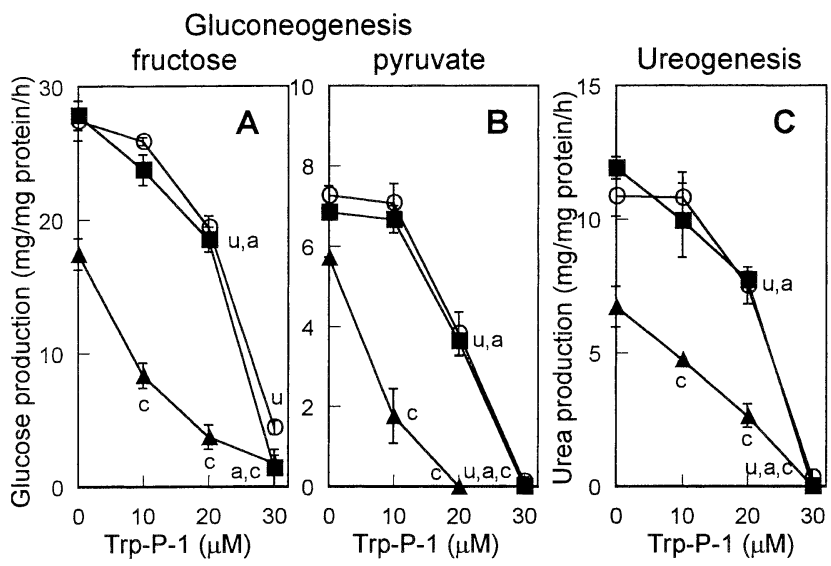

Fig. 2. In vitro effects of food additives and colors on gluconeogenesis and ureogenesis in hepatocytes. Hepatocytes were pretreated with a mixture of food additives $(\mathbf{\square})$ or colors $(\boldsymbol{\Delta})$ for $12 \mathrm{~h}$ and then various concentrations of Trp-P-1 were added for another $12 \mathrm{~h}$ as described in Fig. 1. Control cells $(O)$ were treated with $0.1 \%$ DMSO as a vehicle. Gluconeogenesis from fructose (panel A) or pyruvate (panel B) and ureogenesis (panel C) were measured in the hepatocytes as described in Materials and Methods. Data are mean \pm SE from four independent experiments. Significant effects of food colors were observed against untreated hepatocytes for both gluconeogenesis and ureogenesis $(p<0.05)$ by two-way fractional ANOVA. $\mathrm{u}$, a, and $\mathrm{c}$ designate significant differences between treatment with Trp-P-1 and DMSO in untreated, food additivesand food colors-pretreated cells, respectively $(p<0.05)$, by one-way fractional ANOVA and multiple comparison tests using Scheffe's method as a post-hoc test.

Effect of in vivo-dosed food additives and colors on Trp-P-1induced cytotoxicity

During the preparation of hepatocytes, both food additives and colors did not affect the yields of isolated cells and their viability as judged by the trypan blue exclusion test (data not shown). To determine whether in vivo-fed food additives and colors have a synergistic effect on Trp-P-1-induced cytotoxicity, the cell viability and membrane damage were measured. Trp-P-1 clearly reduced cell viability (Fig. 3A) and increased the LDHleakage (Fig. 3B), as expected, but neither food additives
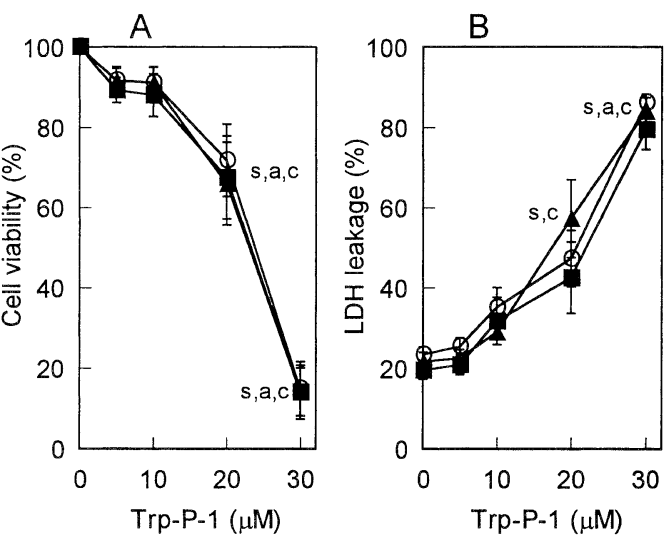

Fig. 3. In vivo effects of food additives and colors on cell viability and LDH-leakage in Trp-P-1-treated hepatocytes. Hepatocytes were separately isolated from rats fed standard diet $(\bigcirc)$, food additives $(\mathbf{\square})$, and food colors $(\mathbf{\Delta})$. After a 6-h-culture, hepatocytes were treated with various concentrations of Trp-P-1 for another $12 \mathrm{~h}$. Control cells were treated with $0.1 \%$ DMSO as a vehicle. Cell viability was measured in hepatocytes by MTT-test (panel A) and LDH-leakage (panel B) as described in Materials and Methods. Data are mean \pm SE from six animals. Diet effect of food additives or food colors was not observed by two-way fractional ANOVA. The effects of Trp-P-1 in each diet group were analyzed by one-way fractional ANOVA and multiple comparison tests using Scheffe's method as a post-hoc test. s, a, and c designate significant differences against DMSO-treated cells from standard-diet-, food-additivesand food-colors-fed rats, respectively $(p<0.05)$.

nor colors showed any synergistic effect of cytotoxicity on these markers. In addition, the same trends were observed in DNA and protein syntheses (Fig. 4): $20 \mu \mathrm{M}$ Trp-P-1 reduced the uptake of ${ }^{3} \mathrm{H}$-thymidine and ${ }^{3} \mathrm{H}-$ leucine into the cells, but neither food additives nor colors facilitated these reductions. These results indicate that food additives and colors neither have toxicity to hepatocytes by themselves in appearance nor have a synergistic effect on Trp-P-1-induced cytotoxicity. Effect of food additives and colors on ureogenesis and gluconeogenesis in Trp-P-1-treated hepatocytes

The activities of gluconeogenesis and ureogenesis in 

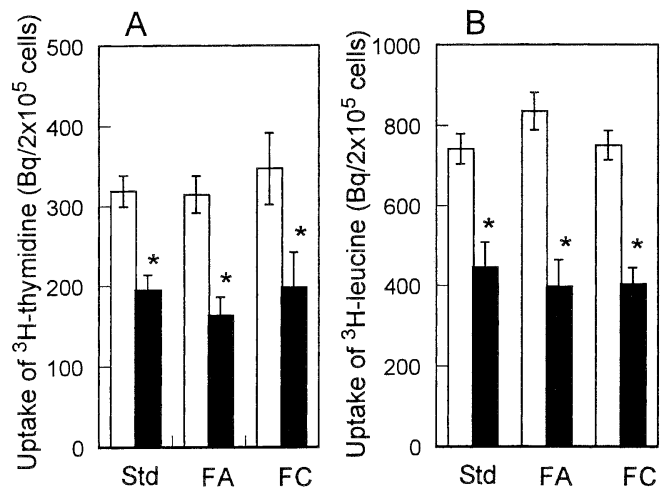

Fig. 4. In vivo effects of food additives and colors on DNA and protein syntheses in Trp-P-1-treated hepatocytes. Hepatocytes were separately isolated from rats fed standard diet (Std), food additives (FA) and food colors (FC), and the cells were treated with Trp-P-1 (closed bar) or DMSO as the vehicle (open bar) as mentioned in Fig. 3. DNA (panel A) and protein (panel B) syntheses were measured in hepatocytes as described in Materials and Methods. Data are mean \pm SE from four animals. A diet effect of food additives or food colors was not observed by two-way fractional ANOVA. Asterisks indicate significant differences between TrpP-1- and DMSO-treated hepatocytes by one-way fractional ANOVA and multiple comparison tests using Scheffe's method as a post-hoc test $(p<0.05)$.

hepatocytes from food additives- or colors-fed rats were measured. As shown in Fig. 5, gluconeogenesis from fructose (panel A) or from pyruvate (panel B) was dosedependently decreased by Trp-P-1. In both cases, hepatocytes from food colors-fed rats were more sensitive to Trp-P-1 than those from standard diet- or food additives-fed rats. A diet effect was not observed for gluconeogenesis, although food colors showed lower values, while food additives tended to have higher values as compared with the cells from standard diet-fed animals. Ureogenesis was also depressed by treatment with TrpP-1 in hepatocytes from rats fed food colors (Fig. 5C), whereas that in the cells from food additives- or standard diet-fed rats tolerated Trp-P-1 up to $20 \mu \mathrm{M}$. A diet effect was detected in that the hepatocytes from food additives-fed rats increased ureogenic activity as compared to the cells from standard diet-fed rats. This effect may be due to the long-term feeding of glutamate in the diet. These results indicate that the feeding of food colors has the potential to suppress liver functions such as ureogenesis and gluconeogenesis when hepatocytes are exposed to Trp-P-1-like dietary carcinogen.

\section{DISCUSSION}

The intake of each food additive or color below the ADI value is considered to be safe for humans. However, processed food contains various kinds of artificial food additives and colors, and the synergistic toxicity of them mutually or with other dietary contaminants is still unknown. Some food additives, not only artificially produced ones but also natural ones, modulate $\mathrm{P} 450$ enzymes at a high dosage $(5-7,25,26)$. Our results

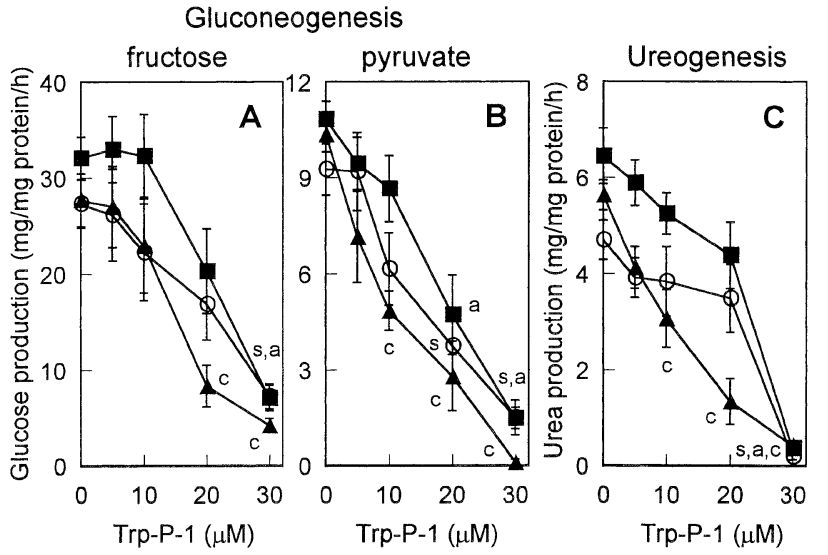

Fig. 5. Synergistic effects of in vivo-administered food additives and colors on gluconeogenesis and ureogenesis in Trp-P-1-treated hepatocytes. Hepatocytes were separately isolated from rats fed standard diet $(\bigcirc)$, food additives ( $\boldsymbol{\square})$ and food colors $(\boldsymbol{\Delta})$, and then cultured and treated with Trp-P-1 as mentioned in Fig. 3. Gluconeogenesis from fructose (panel A) or pyruvate (panel B) and ureogenesis (panel C) was measured in hepatocytes as described in Materials and Methods. Data are mean \pm SE from six animals. On diet effect, ureogenesis in the food additives-fed group was significantly higher than that in the standard diet-fed group $(p<0.05)$ by two-way fractional ANOVA. s, a, and $c$ designate significant differences between Trp-P-1- and DMSO-treated cells from standard diet-, food additivesand food colors-fed rats, respectively $(p<0.05)$, by oneway fractional ANOVA and multiple comparison tests using Scheffe's method as a post-hoc test.

showed that both the mixture of food additives and colors in diets did not modulate the P450 monooxygenase system (Table 1), indicating that animals do not recognize these compounds under our experimental dosages. Furthermore, feedings of both food additives and colors by themselves did not cause any toxicity or disturbance of cellular functions such as gluconeogenesis and ureogenesis. Therefore, hepatocytes from food additives- or colors-fed rats are seemingly normal, and these compounds added in diets are safe for the liver cells of rats, at least, under our experimental conditions.

Trp-P-1, one of the heterocyclic amines, is a wellknown dietary carcinogen $(27,28)$. Recently, we found that Trp-P-1 is cytotoxic to primary cultured rat hepatocytes $(10)$ by inducing apoptosis as a distinct action from carcinogenicity (29). In this study, Trp-P-1 itself caused cytotoxicity and reduced gluconeogenesis in the cells from standard diet-fed rats (Figs. 2 and 5), and these results coincide with our previous report (10). The most interesting result in this study is that hepatocytes from food colors-fed rats showed synergistic effects with Trp-P-1 on gluconeogenesis and ureogenesis (Fig. 5). Although little is known about the effect of food colors on gluconeogenesis and ureogenesis, artificial food colors, especially erythrosine, impair biological functions both in vivo and in vitro. For example, chronic feeding of $4 \%$ erythrosine in a diet promotes thyroid tumor formation $(30,31)$. Erythrosine may in- 
teract with DNA repair enzymes and/or with DNA (32, $33)$, but this color does not show mutagenicity or genotoxicity $(34,35)$. A recent report (33) demonstrated that erythrosine has estrogen-like growth stimulatory properties in human breast cancer cells. Thus, food colors in a diet have a latent potential to injure cellular functions even at a lower dosage.

It is known that in vitro treatment with food colors showed cytotoxicity to cultured cells $(35,36)$. We observed that the mixture of food colors by itself caused not only a significant loss of cell viability but also reductions in gluconeogenesis and ureogenesis (Figs. 1 and 2). Moreover, these cytotoxicities and dysfunctions were synergistically facilitated in the presence of Trp-P-1. Therefore, food colors directly injure cellular functions under the in vitro condition. Artificial food colors reduced mitochondrial respiration by in vitro treatment using mitochondria from the rat liver and kidney (37). In this paper, the MTT test was used to evaluate cell viability, and this test depends upon the activities of mitochondrial dehydrogenases (19). Thus, the loss of cell viability by food colors may be due to the reduction of mitochondrial functions. Mitochondrial enzymes are involved in ureogenesis and gluconeogenesis from pyruvate, and this indicates that the impairment of mitochondria may reduce ureogenesis and gluconeogenesis, at least, in part, under the in vitro condition.

In conclusion, the results in this study suggest that the daily intake of artificial food colors may increase susceptibility to Trp-P-1-induced hepatic dysfunction: the reduction of gluconeogenesis and ureogenesis revealed that food colors do not modulate the drug-metabolizing system even at lower dosages. However, there still remain questions: "How do food colors affect Trp-P1-caused hepatic dysfunction," and "Are the synergistic effects on toxicity revealed with other food contaminants as with Trp-P-1?". To clarify these remaining issues, further studies are needed.

\section{REFERENCES}

1) Waltersack I, Klotz U. 1996. Influence of diet and nutritional status on drug metabolism. Clin Pharmacokinet 31: 47-64.

2) Hietanen E. 1980. Dietary components and cancer. J Toxicol Environ Health 6: 963-969.

3) Statland BE. 1992. Nutrition and cancer. Clin Chem 38: 1587-1594.

4) Ames BN, Gold LS. 1998. The causes and prevention of cancer: the role of environment. Biotherapy 11: 205220.

5) Rochat MH, Vesely DL. 1983. Red dye No. 2 and the red pigment carmine enhance aryl hydrocarbon hydroxylase and guanylate cyclase activities. Biochem Biophys Res Commun 111: 409-414.

6) Verhagen H, Schilderman PAEL, Kleinjans JCS. 1991. Butylated hydroxyanisole in perspective. Chem-Biol Interact 80: 109-134.

7) Guengerich FP. 1995. Influence of nutrients and other dietary materials on cytochrome P-450 enzymes. Am J Clin Nutr 61 (suppl): 651S-658S.

8) Das KC, Herbert V. 1978. The lymphocytes as a marker of past nutritional status: Persistence of abnormal lym- phocyte deoxyuridine (dU) suppression test and chromosomes in patients with past deficiency of folate and vitamin $\mathrm{B}_{12}$. Br J Haematol 38: 219-233.

9) James SJ, Swendseid M, Makinodan T. 1987. Macrophage-mediated depression of T-cell prolification in zinc-deficient mice. J Nutr 117: 1982-1988.

10) Ashida H, Nakai R, Kanazawa K, Danno G. 1998. Xenobiotic tolerance of primary cultured hepatocytes in rats fed a high-fat or high-protein diet. J Nutr Sci Vitaminol 44: 89-102.

11) American Institute of Nutrition. 1977. Report of the American Institute of Nurtition Ad Hoc Committee on standards for nutritional studies. J Nutr 107: 13401348.

12) American Institute of Nutrition. 1980. Second report of the Ad Hoc Committee on standards for nutritional studies. J Nutr 110: 1726.

13) Omura T, Sato R. 1964. The carbon monoxide-binding pigment of liver microsomes. I. Evidence for its hemoprotein nature. J Biol Chem 239: 2370-2378.

14) Omura T, Takesue S. 1970. A new method for simultaneous purification of cytochrome b5 and NADPH-cytochrome $\mathrm{c}$ reductase from rat liver microsomes. $J$ Biochem 67: 249-257.

15) Takesue S, Omura T. 1970. Solubilization of NADH-cytochrome $\mathrm{b} 5$ reductase from rat liver microsomes by lisosomal digestion. J Biochem 67: 259-266.

16) Imai Y, Ito A, Sato R. 1966. Evidence for biochemically different types of vesicles in the hepatic microsomal fraction. J Biochem 60: 417-428.

17) Nash T. 1953. The colorimetric estimation of formaldehyde by means of the Hantzch reaction. Biochem J 55: 416-421.

18) Hiramastu N, Kishida T. Natake M. 1987. Effect of autoxidized linoleic acid on the contents of cytochrome P450 and cytochrome $b_{5}$, and drug-metabolizing enzyme activities in rat liver. J Nutr Sci Vitaminol 33: 37-48.

19) Tanaka K, Sato M, Tomita Y, Ichihara A. 1978. Biochemical studies on liver functions in primary cultured hepatocytes of adult rats. J Biochem 84: 937946.

20) Mosmann T. 1983. Rapid colorimetric assay for cellular growth and survival: Application to proliferation and cytotoxicity assays. J Immunol Meth 65: 55-63.

21) Oka M, Maeda S, Koga N, Kato K, Saito T. 1992. A modified colometric MTT assay adapted for primary cultured hepatocytes: Application to proliferation and cytotoxicity assays. Biosci Biotechnol Biochem 56: 14721473.

22) Bergmeyer HU, Graßl M, Walter H-E. 1983. Reagents for enzymatic analysis: biochemical reagents for general use: enzymes. In: Methods of Enzymatic Analysis (Bergmeyer HU, Bergmeyer J, Graßl M, eds), 3rd ed, Vol 2. p 126-328. Verlag Chemie, Weinheim.

23) Marsh WH, Fingerhut B, Miller H. 1965. Automated and manual direct methods for the determination of blood urea. Clin Chem 11: 624-627.

24) Lowry OH, Rosebrough NJ, Farr AL, Randall RJ. 1951. Protein measurement with the folin phenol reagent. $J$ Biol Chem 193: 265-275.

25) Bamforth KJ, Jones AL, Roberts RC, Coughtrie MWH. 1993. Common food additives are potent inhibitors of human liver $17 \alpha$-ethinyloestradiol and dopamine sulphotransferases. Biochem Pharmacol 46: 1713- 
1720.

26) Kang J-J, Wang H-W, Liu T-Y, Chen Y-C, Ueng T-H. 1997. Modulation of cytochrome P-450-dependent monooxygenases, glutathione and glutathione $S$-transferase in rat liver by geniposide from Gardenia jasminoides. Food Chem Toxicol 35: 957-965.

27) Sugimura T. 1986. Studies on environmental chemical carcinogenesis in Japan. Science 233: 312-318.

28) Eisenbrand G, Tang W. 1993. Food-borne heterocyclic amines. Chemistry, formation, occurrence and biological activities. Toxicology 84: 1-82.

29) Ashida H, Shiotani B, Adachi H, Hashimoto $T$, Kanazawa K, Danno G. 1998. Tryptophan pyrolysis products, Trp-P-1 and Trp-P-2 induce apoptosis in primary cultured rat hepatocytes. Biosci Biotechnol Biochem 62: 2283-2287.

30) Hiasa $Y$, Ohshima M, Kitahori $Y$, Konishi N, Shimoyama T, Sakaguchi Y, Hashimoto H, Minami S, Kato Y. 1988. The promoting effects of food dyes, erythrosine (red 3) and rose bengal B (red 105), on thyroid tumors in thyroidectomized N-bis(2-hydroxypropyl)-nitrosamine-treated rats. Jpn J Cancer Res 79: 314-319.

31) Jennings AS, Schwartz SL, Balter NJ, Gardner D, Witorsch RJ. 1990. Effects of oral erythrosine $\left(2^{\prime}, 4^{\prime}\right.$, $5^{\prime}, 7^{\prime}$-tetraiodofluorescein) on the pituitary-thyroid axis in rats. Tox Appl Phamacol 103: 549-556.

32) Lakdawalla AA, Netrawali MS. 1988. Mutagenicity, comutagenicity, and antimutagenicity of erythrosine (FD and C Red 3), a food dye, in the Ames/Salmonella assay. Mutat Res 204: 131-139.

33) Dees C, Askari M, Garrett S, Gehrs K, Henley D, Ardies CM. 1997. Estrogenic and DNA-damaging activity of red No. 3 in human breast cancer cells. Environm Health Perspect 105 (suppl): 625-632.

34) Haveland-Smith RB, Combes RD, Bridges BA. 1981. Studies on the genotoxicity of some fluorescein dyes. Mutat Res 88: 1-15.

35) Rogers CG, Boyes BG, Matula TI, Héroux-Metcalf C, Clayson DB. 1988. A case report: A multiple end-point approach to evaluation of cytotoxicity and genotoxicity of erythrosine (FD and C Red No.3) in a V79 hepatocyte-mediated mutation assay. Mutat Res 205: 415423.

36) Sako F, Kobayashi N, Watabe H, Taniguchi N. 1980. Cytotoxicity of food dyes on cultured fetal rat hepatocytes. Tox Appl Pharmacol 54: 285-292.

37) Reyes FGR, Valim MFCFA, Vercesi AE, 1996. Effect of organic synthetic food colours on mitochondrial respiration. Food Additiv Contam 13: 5-11. 